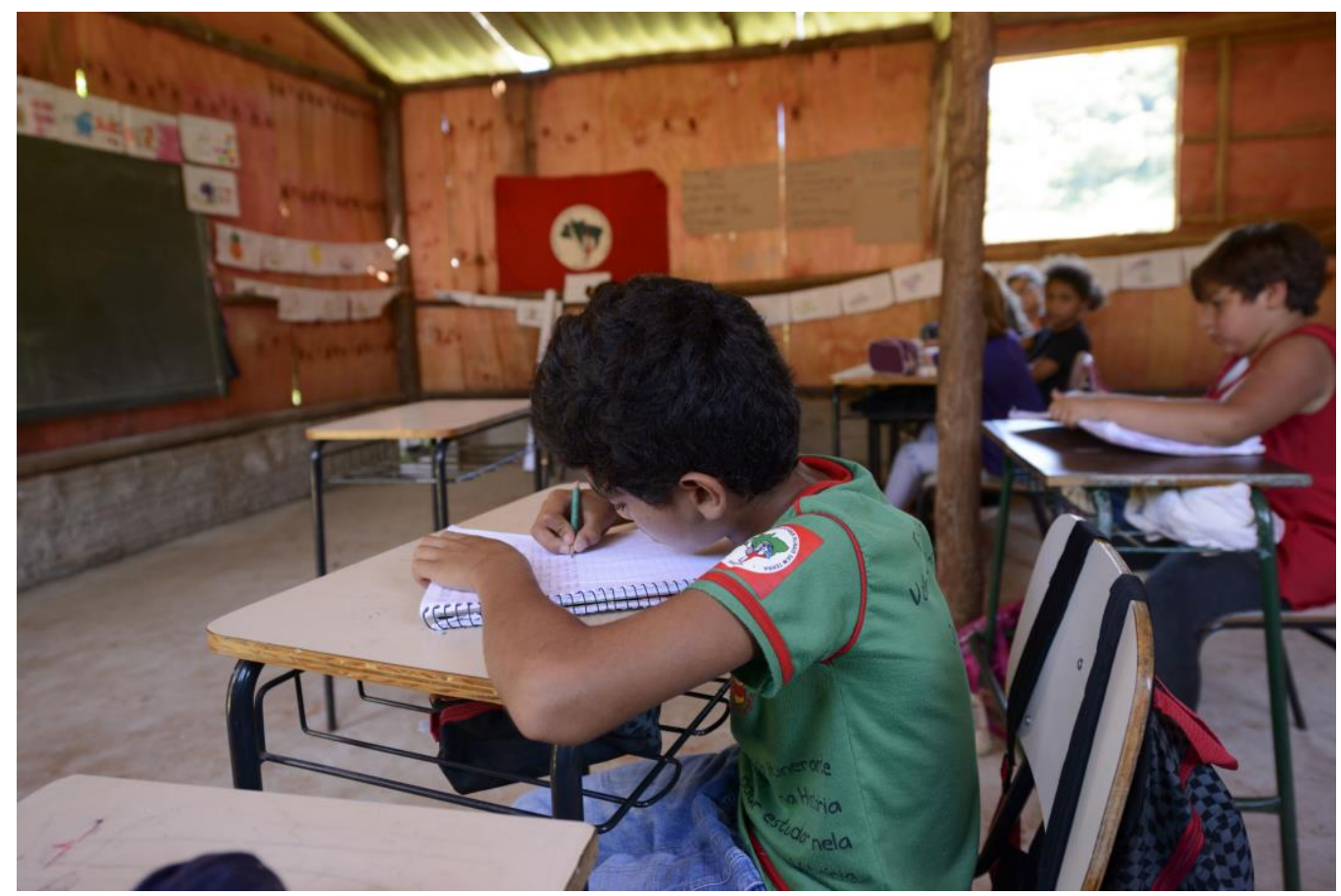

O ritual da mística no processo de identificação e resistência

The ritual of mystic in the process of identification and resistance

Freda Indursky ${ }^{*}$

\title{
Resumo
}

O trabalho examina o ritual da mística em práticas do MST. A mística, designação empregada pelos sem-terra, consiste em acontecimentos sócio-políticos que se manifestam em práticas discursivas e não-discursivas através das quais os sem-terra identificam-se e reidentificam-se com os saberes do MST. Esses rituais simbolizam uma forte economia coletiva do desejo, atualizando a memória de suas lutas em contraposição a saberes-outros, oriundos de campos diferentes e/ou adversos da sociedade.

Palavras-Chave: mística, pulsão político-social, produção coletiva do desejo, prática políticoritualística, identificação/reidentificação, resistência.

\begin{abstract}
The ritual of mystic is examined in the practices of the MST. The mystic, term used by the semterra (landless), encompasses socio-political events manifested in discursive and non-discursive practices by which the sem-terra identify each other and re-identify themselves with the knowledge of the MST. These rituals symbolically inscribe a strong collective economy of desire, updating the memory of their struggles in a movement of resistance to other forms of knowledge, coming from different or opposite fields of society.

Key words: mystic, socio-political pulsion, collective production of desire, political-ritualistic practice, subjectification process, resistance.
\end{abstract}

\footnotetext{
* Doutora pelo IEL/UNICAMP. Professora Titular do Departamento de Letras Clássicas e Vernáculas do Instituto de Letras da Universidade Federal do Rio Grande do sul (UFRGS). Professora colaboradora convidada junto ao Programa de Pós Graduação em Letras/UFRGS. E-mail: freda.indursky@ gmail.com. Universidade Federal do Rio Grande do Sul, Instituto de Letras. Av. Bento Gonçalves, 9500, Agronomias 90540000 - Porto Alegre, RS
} 
Somente a utopia colocada à frente como horizonte maior, tendo a mística como energia real e imediata, consegue dar sentido à coerência e mantê-la sem hesitação.

Ademar Bogo - MST

A mística [...] é a alma da esquerda que produz a garra necessária para combater as injustiças [...]

Pedro Ranulfo - MST

\section{Primeiras palavras}

Anteriormente, examinei diferentes modos de subjetivação/identificação no discurso do/sobre o MST (INDURSKY, 1999; 2005; 2006). No presente trabalho, parto do que já foi apurado nos trabalhos anteriores, mas a indagação que conduz o momento atual de minha investigação é distinta.

É sabido que as pessoas que ingressam nas fileiras do MST vêm de diferentes regiões e têm um entorno cultural bastante diversificado: pessoas do meio rural que buscam um pedaço de terra para dela tirar sua subsistência; trabalhadores rurais que foram dispensados em função da mecanização dos trabalhos no campo; filhos de exsem-terra, assentados juntamente com seus pais, que retornam aos acampamentos, pois, agora, adultos e já com sua própria família constituída, necessitam de seu próprio pedaço de chão, pois a terra de seus pais é pouca para prover a todos. Mas essa não é a única situação dos acampados. Outros segmentos também aí se encontram, entre eles pode-se citar alguns sem-teto, os sem-emprego e, mais recentemente, os brasiguaios $^{1}$ que retornam ao Brasil e inscrevem-se nas fileiras do Movimento dos trabalhadores Sem Terra (MST). Desse modo, é possível perceber que os sem-terra acampados constituem um grupo bastante heterogêneo.

Em função dessa diversidade, comecei a indagar-me de que modo esses acampados e até mesmo os assentados, tão diferentes entre si, são interpelados a se identificarem com o MST e com os saberes dos trabalhadores rurais. Acredito mesmo

\footnotetext{
${ }^{1}$ Brasiguaio é a designação que está sendo dada a brasileiros que emigraram para o Paraguai na segunda metade do século passado, em busca de terras agriculturáveis. Parte deles estão retornando em função de conflitos com os sem-terra paraguaios. No momento, oriento a Tese de Doutorado Discursos, memórias e representações identitárias: os brasiguaios dos dois lados da linha de Rosemere de Almeida Aguero, em que esta complexa situação é analisada.
} 
que muitos podem identificar-se com a questão agrária, mas isso não é suficiente para transformá-los em militantes da causa Sem Terra ${ }^{2}$.

Em trabalhos anteriores, verifiquei que os porta-vozes e as lideranças do Movimento formulam demandas ao Estado; eles pertencem ao que, dentro do MST, chamam de coordenadores nacionais e regionais (INDURSKY, 2000; 2013). Mas e aqueles que estão acampados e apenas desejam um pedaço de chão para viver e cultivar, como se identificam com essa causa? Como são capturados pela Forma-Sujeito que organiza a FD Sem Terra? No meu entendimento, esse processo de interpelação é feito, pelo menos ${ }^{3}$, de duas formas: a. pelo viés do que, no MST, é conhecido como mística; e b. através da educação. E é mística e seu funcionamento político que vou analisar neste trabalho. Para tanto, passarei rapidamente também pela educação que, como veremos, acaba por entrelaçar-se fortemente à prática ritualística da mística.

Mas o que é a mística? Originariamente, podemos situá-la na ordem do religioso e este fato pode ser percebido como um dos vestígios mais evidentes do vínculo inicial que existiu entre o MST e a Igreja Católica, através da Pastoral da Terra. Nesse discurso religioso, a mística trata da relação do homem com Deus através da contemplação. Como exemplo, podemos citar a mística de São João da Cruz ${ }^{4}$.

Ao longo do século XIX e nas primeiras décadas do século XX, é possível identificar movimentos político-religiosos de norte a sul do Brasil em que a mística fez-se fortemente sentir pela presença de beatos que encarnavam o que passou a ser conhecido como messianismo. Dentre eles, podemos destacar Antônio Conselheiro, no sertão baiano5; o Beato José Maria, no âmbito da Revolta do Contestado, na fronteira entre SC e PR ${ }^{6}$; e a beata Jacobina ${ }^{7}$, na Revolta dos Muckers, em Sapiranga, RS. Tomo

\footnotetext{
${ }^{2}$ Neste ponto, desejo distinguir Sem Terra de sem-terra. Oponho estas duas designações, para melhor distinguir o militante sem-terra da FD Sem Terra, organizada pela Forma-Sujeito Sem Terra que agrega todos os saberes relativos aos sem-terra. Embora sejam muito próximas uma da outra, não se superpõem.

${ }^{3}$ Segundo Marco Fernandes (2011), a experiência de participar de uma ocupação e de permanecer em um acampamento, trocando experiências e vivências com os demais acampados, funciona como uma mística bastante suficiente para interpelar aqueles indivíduos em sujeitos. Não é deste tipo de mística que vou me ocupar neste trabalho,

${ }_{5}^{4}$ Juan de la Cruz, místico espanhol, foi uma das mais importantes personalidades da Contra-Reforma.

5 Antônio Conselheiro liderou o arraial de Canudos, nos anos 70-90 do século XIX. Lá reuniram-se sertanejos, índios e escravos recém-libertos que consideravam o Conselheiro um "homem santo".

${ }^{6}$ A Guerra do Contestado - 1912 a 1916 - ocorreu em função de disputa de terras na fronteira entre Paraná e Santa Catarina. Os agricultores contestaram a doação de terras por eles ocupadas à Brazil Railway Company. A contestação reuniu agricultores, trabalhadores demitidos pela companhia e alguns fazendeiros, mas sem resultado algum. Em função disso, reuniram-se em torno do Beato José Maria.

${ }^{7}$ A Revolta dos Muckers, Sapiranga, RS, ocorreu no final do Séc. XIX, entre os primeiros emigrantes alemães, já em condições financeiras mais estáveis, e um segundo grupo, muito pobre, chegado posteriormente e que se dedicava ao cultivo da terra. Esse grupo de camponeses estava envolvido em um movimento messiânico liderado por Jacobina Menz Maurer. Mucker, em alemão, significa falso santo .
} 
estes três casos para representar a diversidade das situações e para apontar sua presença em praticamente todo território nacional.

Algo semelhante teria ocorrido no âmbito do Movimento Sem Terra? Em primeiro lugar, é preciso salientar que a mística, nas práticas do MST, de fato faz ressoar no discurso desse Movimento a memória de sua origem religiosa, porém, a mística, ao ser inscrita no âmbito das práticas do MST, é ressignificada, tomando contornos diferentes. E, o primeiro deles, decorre do fato de que, nesse movimento, não há messianismo ${ }^{8}$. A mística do MST foi efetivamente apropriada da FD Religiosa Católica e inscrita na FD Sem Terra e, ao migrar de um domínio de saber para o outro, carregou consigo traços do religioso, sem, entretanto, visar a experiência divina. Ao contrário. Sua visada é substantivamente terrena, sem nenhum jogo de palavras. Em sua transformação, a mística na FD Sem Terra ritualiza o político e não o religioso. Com base nisso, entendo que a mística do MST é uma prática político-ritualística que acompanha as ações do MST e, através da quais, a Forma-Sujeito Sem Terra interpela os sem-terra, convertendo-os de indivíduos acampados em sujeitos identificados com os saberes e as práticas do MST. E essa captura se realiza pelo viés do sujeito desejante ${ }^{9}$. Por conseguinte, a mística pode ser vista como um instrumento de formação política, ligado tanto à militância quanto ao recrutamento de militantes.

Para pensar o funcionamento desse sujeito desejante, mobilizei (INDURSKY, 2013) a reflexão de Guattari (1986). Para este autor, a produção da fala, das imagens, do desejo não tem origem no indivíduo. "Essa produção é adjacente a uma multiplicidade de agenciamentos sociais". (GUATTARI \& ROLNIK, 1986: 32) (O destaque é meu). E mais adiante, acrescenta que a produção do desejo é resultante de pulsões de natureza político-social: "Trata-se, diz Guattari, de movimentos de protesto do inconsciente contra a subjetividade capitalística (sic), através de outras maneiras de ser, outras sensibilidades, outra percepção, etc." (Ibidem, nota 5: 45) (Os destaques são meus).

Pelo que precede, percebe-se que Guattari alia saberes da Psicanálise a saberes do Marxismo e, assim procedendo, desloca a noção de pulsão do psiquismo do

\footnotetext{
${ }^{8}$ O rei português D.Sebastião, desaparecido na Batalha de Alcácer Quibir, em 1578, passou a ser esperado e cantado como um novo "messias". Desta espera surgiu o sebastianismo em Portugal e, segundo Jacqueline Hermann (2010), os cristãos-novos, ao desembarcarem no Brasil-Colõnia, trouxeram consigo a espera messiânica.

${ }^{9}$ Em outro artigo - A emergência do sujeito desejante no discurso do MST (2013)- trato especificamente desse traço do sujeito do discurso do MST.
} 
indivíduo para o âmbito do sujeito político, abrindo espaço para a concepção de um sujeito desejante na ordem do social.

Desse modo, a mística nas práticas do MST mobiliza o sujeito desejante cuja pulsão $^{10}$ é de natureza político-social. Essa pulsão político-social se materializa nas místicas que se fazem presentes nas práticas do MST e sustentam a produção coletiva do desejo dos sujeitos que se identificam com os saberes da FD Sem Terra ${ }^{11}$. Essas místicas podem assumir formas diferenciadas, visando todas o reforço da identificação desses acampados com a causa da FD Sem Terra e seus saberes. Por seu viés, seus organizadores buscam a construção de uma identidade Sem Terra. A mística é, pois, no contexto do MST, da ordem do político. Através dessas práticas ritualísticas, os acampados são capturados pela ideologia e se identificam com a Forma-Sujeito Sem Terra ou, ainda, por seu viés reafirmam sua identificação.

As místicas costumam acontecer nos mais diferentes espaços como acampamentos, assentamentos, encontros, congressos, tomando a forma de hinos, poesias, cantos, palavras de ordem, encenações, para apenas apontar alguns exemplos. E, nelas, os símbolos do movimento sempre se fazem presentes e são parte constitutiva da mística bandeiras, bonés, camisetas, foices, pás. Diria que esses rituais, por outro lado, dão sustentação às ações e demandas do MST, servindo como elementos potencializadores da capacidade de luta, como veremos mais adiante ${ }^{12}$.

Passo, na seção seguinte, a descrever duas místicas a partir das quais vou refletir sobre o funcionamento discursivo dessas prática político-social.

\section{Duas místicas como objeto de análise}

As duas místicas que vou aqui apresentar ocorreram na Universidade de Ujuí (UNIJUÍ), RS, e me foram relatadas por uma então docente daquela Instituição,

\footnotetext{
${ }^{10}$ Segundo Freud (1915), a pulsão não se dá a conhecer por si mesma. Ela é reconhecida pelo viés das ideias (Vorstellung) e do afeto (Affekt).

${ }^{11}$ Não estou afirmando que as místicas praticadas pelos sujeitos identificados com a Formação Ideológica que subjaz aos saberes do MST são a única forma de materialização da pulsão político-social que move esse coletivo. Mas entendo que elas sustentam a continuidade dessa identificação frente às adversidades a enfrentar em sua vida de acampados.

${ }^{12}$ Segundo Marco Fernandes (2011), em sua série de artigos intitulada "Luta, que cura!", publicados no Site Passa Palavra (http://passapalavra.info/2011/05/40366 ), frequentemente a mística tem sido considerada pelos acampados do Movimento dos Trabalhadores sem Teto (MTST) como uma terapêutica, marcando, desta forma, a força política deste ritual e acentuando desta forma as relações já apontadas mais acima entre o Marxismo e a Psicanálise. Aproveito para agradecer ao Dr. Rodrigo Almeida Fonseca pela indicação destes artigos.
} 
encarregada do módulo de Língua Portuguesa ${ }^{13}$ do Curso de Pedagogia, estruturado especialmente para a formação de professores Sem Terra. Não disponho de nenhum registro escrito, nenhuma foto, apenas o referido relato que, após ter sido descrito, foi submetido a minha informante para que pudesse ser aqui apresentado da forma mais fiel possível, sem distorções. Na ausência de um registro, vou apresentar a descrição desses eventos para, a seguir, tomá-los como objeto de análise. Vou intitular essas místicas para facilitar sua referência. A primeira receberá como título As místicas de sala de aula e a segunda A mística da formatura. Passemos, pois, às descrições.

\section{As místicas de sala de aula}

Em 1999, o MST estabeleceu um convênio com a UNIJUÍ para que fosse estruturada uma Licenciatura destinada à formação de Professores Sem Terra que, por sua vez, garantissem a educação dos sem-terrinha, forma como eles se referem a suas crianças, residentes em acampamentos e assentamentos. $\mathrm{O}$ objetivo dessa Licenciatura era buscar a formação de professores que atendessem aos interesses/objetivos/saberes Sem Terra, os quais nem sempre coincidem com os saberes da Escola Tradicional. Essa demanda permite identificar uma tomada de posição por parte das lideranças do Movimento sobre a questão da educação de seus filhos.

A demanda em questão foi concretizada e os Sem Terra passaram a frequentar o Curso de Formação Pedagógica na UNIJUÍ. Em todas as aulas (pelo menos nas do núcleo de Língua Portuguesa), antes que se iniciasse o trabalho, uma bandeira do MST era colocada sobre a mesa e os estudantes sem-terra cantavam hinos. Ao término das aulas voltavam a entoar suas canções, cujas letras remetiam aos seus saberes e suas metas e só então a bandeira era recolhida. Esse ritual atualizava, a cada vez, a memória de seu lugar social.

Este funcionamento lembra duas práticas diversas. Por um lado, a hora cívica em que, nas escolas, é(ra) hasteada a bandeira e cantado o hino nacional. E, por outro, o ritual de escolas religiosas que inicia(va)m e termina(va) $\mathrm{m}^{14}$ as aulas, fazendo uma oração. Vê-se que o religioso cedeu lugar ao político, com a transformação de uma prática religiosa em uma prática político-ritualística que também absorveu e ressignificou o momento cívico. Assim como a oração reafirma a fé e marca a pertença

\footnotetext{
13 Aproveito para agradecer à professora Dra. Ercília Ana Cazarin pelo relato preciso e precioso das místicas que vou tomar como objeto de análise do presente trabalho.

${ }^{14}$ Grafo assim por não ter conhecimento se esta prática ainda existe.
} 
dos fiéis a uma comunidade religiosa, os hinos e a bandeira do Movimento reafirmam a crença na luta pela terra e o lugar de pertença desses sem-terra. Da mesma forma, assim como a hora cívica marca a identificação com os símbolos pátrios, a bandeira do Movimento e seus hinos marcam sua identificação com a causa Sem Terra. E pelo breve espaço-tempo de uma aula aquela sala se transformava, pelo viés daquele ritual da mística, em território do MST.

Em uma ocasião, a professora encostou-se na mesa sobre a qual se encontrava a bandeira e sobre ela colocou a mão, o que gerou protesto imediato por parte dos estudantes sem-terra, pois a bandeira tinha que ser "respeitada". Isso deixa mais uma vez visível o vestígio do cívico e do religioso no político: para esses estudantes, a bandeira era "sagrada" e como tal devia ser "respeitada". Trata-se do entrelaçamento entre o sagrado, vestígio do religioso, e o político, fortemente representado pelo protesto.

Essas místicas de sala de aula permitem observar como a identificação e, por seu viés, o processo de subjetivação vão sendo reiteradamente reatualizados nas atividades do dia-a-dia desse coletivo.

\section{A mística da formatura}

Quando esse grupo concluiu seu Curso, foi chegada a hora da formatura. E, como não poderia deixar de ser, a mística foi parte constitutiva dessa solenidade. Para distinguir a formatura de professores Sem Terra da formatura de professores da Escola Burguesa, no dia da formatura o MST colocou no palco do Salão de Atos da UNIJUÍ, além da bandeira e de seus demais símbolos, uma certa quantidade de terra. Era a mística funcionando novamente, para tornar visível o não visível: a luta pela terra.

Aquela porção de terra tinha como efeito de sentido relembrar tanto aos formandos quanto à Universidade o pertencimento daqueles formandos a um outro lugar social, diferente daquele em que se encontravam. E aquela terra sobre o palco da UNIJUÍ teve um outro efeito de sentido: transformou aquele palco temporariamente em terra de Sem Terra. Aquele momento, por si só, funcionou como um acontecimento histórico para o Sujeito Sem Terra, o qual foi politicamente ritualizado através daquela mística.

Estas são as duas místicas que serão tomadas, neste trabalho, como objeto de análise. Antes, porém, de encetar essas análises, abro um parêntese para refletir um pouco sobre Educação, pois há uma pergunta que se impõe: porque as lideranças Sem 
Terra entendem ser necessária uma licenciatura específica para os professores que atendem seus filhos?

\section{A Educação Pública e o MST}

Para responder a este questionamento, é preciso examinar, antes de mais nada, o que sucede/sucedia na Escola Pública de modo geral. Para tanto, lembremos que a escola pública, até os anos 60 do século passado, sempre foi de qualidade, mas restrita à classe média. A população escolar era bem mais reduzida. Na década de 70, o Governo Militar, através da Lei 5692/71, decidiu “democratizar" a educação, abrindo as portas das escolas para as classes trabalhadoras.

Este ato, tomado nele mesmo, foi muito importante e já deveria ter sido realizado há muito tempo, pois havia uma parcela significativa da população que não chegava à escola ou que nela permanecia no máximo de dois a três anos, o tempo suficiente para aprender a fazer alguns cálculos básicos, saber produzir uma leitura funcional, escrever alguma coisa, assinar o nome. Por conseguinte, a chegada e a permanência dos filhos da classe trabalhadora na escola era essencial. Mas é bom lembrar que não bastava abrir as portas ao povo. Era preciso, antes, avaliar as diversas implicações de tal ato para que ele não fosse apenas pró-forma, bem como se fazia imperioso prever formas de acompanhamento dessa abertura para que ela fosse bem sucedida. Entretanto isso não sucedeu. Ao contrário, essa transformação do público alvo da Escola foi feita sem grandes reflexões, sem o adequado preparo dos professores que iriam trabalhar com este novo alunado, diferente daquele a que estavam habituados, um alunado que não pertencia à classe média ${ }^{15}$, que falava uma variedade linguística diversa, que não tinha hábitos de leitura, que trazia experiências de vida muito distintas daquele aluno de classe média que estava inserido na escola há já bastante tempo. Ou seja: a abertura das portas da escola promoveu em lugar de um encontro, um verdadeiro desencontro entre professores e alunos, por um lado, e entre os próprios alunos, por outro.

\footnotetext{
${ }^{15}$ As Secretarias de Educação (pelo menos, no RS), sob a determinação do Ministério de Educação, criaram cursos para "reciclar" os professores da rede pública, com o objetivo de prepará-los para essa mudança. Essa reciclagem foi muito rápida. Em primeiro lugar, visava familiarizar os professores com a nova legislação. E também procurava "modernizar" o ensino, nele introduzindo novos conhecimentos. Novamente refiro-me ao que sucedeu com professores atuando em Língua Portuguesa, em Porto Alegre, onde vários professores da rede pública eram oriundos de cursos universitários onde já se estudava a Teoria da Comunicação e a Análise Gerativa estava sendo aplicada à Língua Portuguesa. Esses conhecimentos deslizaram dos bancos universitários para os escolares sem muitos questionamentos. E isso sucedeu exatamente no momento em que os filhos das classes trabalhadoras estavam chegando à escola. Diria que esse alunado e suas necessidades estavam muito distante dos saberes dos professores que iriam com eles trabalhar.
} 
Aí iniciou, em minha opinião, o desmonte da Educação Pública, pois os professores não estavam preparados para essa mudança. Aos currículos foram introduzidos improvisadamente cursos profissionalizantes sem preparar os professores para esta tarefa. Tais cursos, na verdade, não profissionalizavam ninguém e as poucas escolas técnicas até então existentes foram mal aproveitadas.

Tomo, para falar do que se passou nas escolas, na década de 70 do século passado, o caso específico da disciplina de Língua Portuguesa, espaço em que atuava naquele momento. Os professores da Escola Pública, acostumados a trabalhar com alunos oriundos da Classe Média, não estavam preparados para lidar com a variedade linguística dos filhos das classes trabalhadoras que passaram a frequentar suas salas de aula. Em função disso, tacharam tal variedade de errada, tanto em sua modalidade oral como escrita.

Se a variedade de língua materna com a qual esses sujeitos se identificavam e por seu viés se subjetivavam era (é) considerada "errada" e se os professores não sabiam(sabem) como conduzi-los na passagem dessa variedade linguística à língua padrão, esses sujeitos foram condenados a permanecer à margem, foram literalmente silenciados, separados do mundo ao qual a escola deveria dar-lhes acesso. Não é, pois, de admirar o surgimento do mito de que "a língua portuguesa é difícil" e que "não sabem nada de português". Ouvi isso reiteradamente, a cada vez que respondi à pergunta sobre que disciplina lecionava. E até mesmo os alunos de Letras pensavam assim.

Trago uma reflexão de Pêcheux para promover um melhor entendimento do que se passava então (e, na minha opinião, ainda se passa) na Escola Pública: toda língua, nos diz ele, através de suas estruturas está necessariamente em relação com o "não está", o "ainda não estâ" e até mesmo com o "nunca estará". Nela [na estrutura da língua] "se inscreve assim a eficácia omni-histórica da ideologia como tendência incontornável a representar [...] os fins últimos, o alhures e o invisível. (PÊCHEUX, 1982/1990, p. 9) (O destaque é meu.). Essa foi e, em minha opinião, ouso dizer que ainda é a formação ideológica que sustentou então e ainda embasa a prática de sala de aula de Língua Portuguesa na Escola Pública.

Ou seja, a democratização da Escola Pública foi uma ilusão, uma fachada para continuarem a ser reproduzidas as desigualdades presentes na estrutura social. Ou seja: foi implantada uma mudança para que tudo continuasse como estava: manter o povo alijado da Educação. Concretamente, o Estado democratizou o acesso à escola, ao seu 
espaço material e público, mas não à educação. Esta é a contradição que sustenta a trágica situação que ainda hoje persiste na Educação Pública brasileira. Para melhor entendermos isso, ouçamos Foucault:

"...a educação, embora seja, de direito, um instrumento graças ao qual todo indivíduo [...] pode ter acesso a qualquer tipo de discurso, segue, em sua distribuição, no que permite e no que impede, as linhas que estão marcadas pela distância, pelas oposições e lutas sociais. Todo sistema de educação é uma maneira de manter ou de modificar a apropriação dos discursos, com os saberes e os poderes que eles trazem consigo." (FOUCAULT, 1970/1996, p. 44).

Espero ter podido salientar, mesmo que brevemente, que as mudanças curriculares feitas nos anos 70 no século passado serviram não para modificar o modo de apropriação dos saberes, nem, tampouco, para garantir o acesso democrático a esses saberes, mas, ao contrário, se transformaram em um instrumento que serviu para manter e aprofundar as desigualdades na apropriação dos saberes.

Em função do exposto, espero ter podido responder à pergunta feita ao final da seção anterior e, assim, esclarecer a demanda do MST: tomar em mãos a educação de seus filhos para modificar os rumos da escola tradicional e assim garantir uma escola capaz de formar os sem-terrinha a partir da história de luta e dos saberes Sem Terra, uma Educação que respeite o lugar social a que pertencem seus pais e, por conseguinte, seus filhos. Formá-los adequadamente para assumir a continuidade da luta pelo direito à terra, pela justiça social na terra.

Percebe-se que o Setor de Educação do MST tinha bem claro que a Escola Pública, tal como está(va) concebida, é um aparelho ideológico destinado a reproduzir as desigualdades sociais. E era isso que o MST pretendia superar com seu Projeto. Nesse ponto, vale lembrar a palavra de Bauman:

Se a legislação estabelece a agenda, dividindo as opções teoricamente possíveis entre as que são permitidas e as que são proibidas e puníveis, a educação desempenha sua função codificante, subdividindo o conjunto de opções disponíveis/permitidas entre as que são desejáveis/recomendáveis/adequadas e as indesejáveis/não recomendáveis/inadequadas. (BAUMAN, 1999/2000, p. 79.)

A reflexão de Bauman ilumina bem a opção feita pelo Setor Educacional do MST: em lugar da escola pública tradicional ${ }^{16}$, inadequada para a formação dos sem-

\footnotetext{
${ }^{16}$ A classe média foi colocada diante desse impasse também, pois a Escola Pública já não atendia suas expectativas em relação à educação de seus filhos. E sua "opção" foi a de encaminhá-los para a Escola
} 
terrinha, o movimento passou a lutar pela escola desejável para seus filhos, uma escola capaz de respeitar a identidade política dos Sem Terra e, por conseguinte, capaz de participar da formação dos filhos Sem Terra e de seu processo de identificação com a causa que mobilizou seus pais, garantindo, dessa forma, para a geração seguinte, a construção de uma identidade Sem Terra pelo viés de uma escola que trabalhe com a economia do ponto de vista da distribuição de terras e de uma agricultura familiar e se posicione contra o latifúndio, o agronegócio e os transgênicos, entre outros de seus saberes, por exemplo. Enfim, uma escola que leve em conta as condições de vida e de luta dos Trabalhadores Rurais sem Terra.

Da mesma forma, o Setor de Educação do MST se deu conta de que a passagem da escola tradicional estatal para o seu objeto de desejo - uma escola estatal que atenda à formação desejável e adequada dos sem-terrinha - implicava pensar e propor uma pedagogia adequada aos saberes do MST. Sobre essa questão, podemos ler em Camini, uma das pensadoras da pedagogia do MST:

Tendo presente que a escola pública e os professores em nosso estado vêm enfrentando problemas dos mais diversos; que a realidade das escolas do meio rural apresenta-se precária e ainda ausente nos debates sobre a educação pública; que o ensino em geral é fraco e fragmentado e seus professores carecem de formação e capacitação continuada para que possam pensar a prática cotidiana a partir de um conhecimento teórico necessário para refleti-la é que o Setor Nacional de Educação do MST tem se preocupado, desde o início, em pensar estrategicamente como viabilizar a escola para as crianças assentadas. (CAMINI, 1998, p. 59) (Grifo da autora).

A partir dessa citação e considerando o destaque que nela fiz, percebe-se que a escola rural, já existente, teoricamente poderia atender às necessidades dos sem-terra e de seus filhos, porém também não atendia/atende às necessidades educacionais do Movimento, o que, uma vez mais, reforça as razões que moveram os educadores do MST para conquistar uma licenciatura específica para a escola de sem-terra. Vale a pena, ainda, observar como essa questão foi se delineando. Para tanto, vejamos o que diz Caldart, também membro do Setor de Educação do MST:

Três momentos para a metáfora da ocupação da escola. Primeiro momento: a luta pela escola na luta pela terra. Ou: somos Sem Terra sim senhores, e exigimos escola para nossos filhos! Segundo momento: a inserção da escola em uma organização social de massas. Ou queremos estudar em uma escola do MST! Terceiro momento: a

Privada. O que nos permite perceber que a Escola Pública não está(va) atendendo aos interesses nem da classe média nem da classe dos trabalhadores. 
escola do MST e a formação dos sujeitos de um projeto popular de educação e de país. Ou: Somos Sem Terra, somos brasileiros, temos o direito e o dever de estudar! (CALDART ${ }^{17}, 2000$, p.153) (Os destaques são meus).

Pelas metáforas presentes na citação de Caldart, vê-se como as demandas vão, pouco a pouco, ampliando os horizontes do que seria o perfil de uma educação específica para os sem-terrinha. De início, exigiam apenas o direito de suas crianças poderem estudar. Isso remete ao fato de que algumas escolas, por razões econômicas, foram fechadas, determinando tal medida que as crianças fossem obrigadas a estudar longe de casa, frequentemente em escolas urbanas, precisando viajar ou fazer longas caminhadas a pé. Mas não só. Muitas vezes, crianças de diferentes níveis de escolaridade são colocadas em uma mesma sala, atendendo uma vez mais à racionalização dos recursos humanos e materiais ${ }^{18}$. Nada disso favorece uma boa educação.

Tais discrepâncias determinaram, em um segundo momento, a demanda por uma escola específica para os sem-terrinha. Claro que essa demanda vinha alicerçada no tratamento dispensado às escolas rurais, cujo currículo não contemplava as questões específicas de quem vive no campo e não tem terra e cujos professores tampouco estavam preparados para pensar tais questões.

Tais restrições determinaram, por conseguinte, o terceiro momento no qual passaram a reivindicar a formação de seu próprios quadros para a atuação nas escolas públicas destinadas aos sem-terrinha. Dessa forma, teriam finalmente todos os elementos reunidos: seus filhos matriculados numa escola do MST com professores especificamente formados para a tarefa de construir um currículo adequado a uma educação que contemple os saberes e conhecimentos do MST, e que seja capaz de repassar às jovens gerações bandeiras, sonhos e projetos do Movimento.

Como se vê, os sentidos de um dos lemas do Movimento - "Ocupar, Resistir, produzir" - deslizaram sob a ação do Setor de Educação do MST para "Ocupar,

\footnotetext{
${ }^{17}$ Camini e Caldart também buscaram sua formação, realizando suas dissertações de mestrado em Educação e tomando o MST como objeto de reflexão.

18 Tais fatos, muito frequentes, ocorreram durante o Governo Yeda Crusius (PSDB), no RS. Sua Secretária de Educação colocou em prática o raciocínio de uma empresa privada de educação, priorizando a racionalização dos recursos humanos e financeiros e sacrificando os interesses dos educandos. Foi nessa gestão, igualmente, que as escolas itinerantes do MST, pensadas para acompanhar os sem-terrinha nos deslocamentos de seus pais, em função de sua mobilidade política, foram fechadas e assim permanecem até hoje.
} 
Resistir, Produzir também na Educação". ${ }^{19}$ Ou seja: a educação é tão importante quanto a ocupação de terras para o Movimento. Aliás, uma remete à outra, em um processo semântico que vai se desdobrando de paráfrase em paráfrase, formando um processo metafórico em espiral: "sem educação não há ocupação que dure", "sem educação não é possível formular políticas de ocupação", "sem educação não há como fazer reforma agrária", "sem educação não há resistência às políticas governamentais" , "sem educação não há como formular uma política agrária", "sem educação não há solução para os Sem Terra", etc. E nessa espiral, uma palavra pela outra vai construindo a identificação desse sujeito.

Cada um desses estágios representou, em um determinado momento das lutas do MST, um sonho utópico, sonho que se converteu em demanda a qual, por fim, se tornou realidade: uma conquista do sujeito desejante cuja pulsão é de natureza político-social. E é um momento dessa trilha que estamos examinando nesse momento: a conquista de um Curso de Pedagogia específico para a formação de professores para as escolas do MST. Chegando neste ponto, fechamos esse longo parêntese que abrimos para retornar às duas místicas descritas em seção anterior.

\section{Analisando as místicas educacionais}

A conquista de um Curso de Pedagogia específico para a formação de quadros para as escolas de crianças do MST é um feito ímpar, é um acontecimento histórico, mas não basta, por si só, para garantir o modo de operacionalizar um curso desta natureza, que atenda os objetivos do Setor de Educação do MST, pois os professores que ministravam esses cursos não estavam necessariamente preparados para pensar a escola desejável à causa Sem Terra, cujos saberes não fizeram parte de sua formação, nem a "terra" é seu lugar de pertença. É claro que havia disponibilidade por parte da Universidade; claro está, também, que havia disponibilidade por parte dos professores que se propuseram a colaborar com essa experiência. No entanto, por mais que estes professores se identificassem com a causa Sem Terra, nem sempre saberiam se colocar no lugar social de um sem-terra ou de um acampado, pois não eram movidos pelas questões que levam os sem-terra a acreditar que têm direito de lutar pelo direito à terra.

Alianças e simpatia tanto institucional quanto por parte dos professores que se engajaram no projeto certamente existiam e foram estes os elementos de partida para a execução do Projeto. Mas, nas salas de aula, também havia espaço para diferenças,

\footnotetext{
${ }^{19}$ Este lema deu título para a dissertação de mestrado de Ivana Acunha Guimarães por mim orientada: Ocupar, resistir, produzir também na educação: uma análise do discurso pedagógico do MST
} 
divergências, tensões. E, em função disso, se um professor se afastasse, mesmo que minimamente, do modelo idealizado para a formação pretendida, cada vez que mobilizasse um saber contrário aos dos Sem Terra, cada vez que um de seus símbolos não era "respeitado", (como vimos na descrição da mística de sala de aula acima apresentada), desencadeava-se, em contrapartida, um movimento de resistência ${ }^{20}$ materializado pela mística de sala de aula.

Através de seus cantos, de seus hinos, de sua bandeira os estudantes sem-terra produziam não apenas um movimento de resistência em relação ao deslizamento de saber ou ao modo de se colocar do professor, afetado por outra FD, como também produziam um processo de reidentificação com os saberes da FD Sem Terra, resultando dessa resistência um "retorno do Sujeito no sujeito", uma "reduplicação da identificação" (PÊCHEUX, 1975/1988, p.172). Rememoravam pelo viés dessas místicas quem eram e o que vieram procurar na Universidade. E, assim procedendo, produziam um movimento para dentro, voltado para eles próprios, destinado a lembrarlhes de onde vinham e o que ali vieram buscar, sinalizando pelo viés da mística que seus saberes são diversos, que não pertenciam àquele lugar e que ali estavam de passagem para fazerem sua formação pedagógica. Mas, paralelamente a esse movimento de reafirmação de seu lugar de sem-terra que a mística lhes proporcionava, havia um outro movimento igualmente provocado pela mística. E esse segundo movimento era para fora, dirigia-se ao professor que estava ali para ministrar-lhes aulas. A mística servia para lembrar também ao professor quem eram os estudantes que ali se encontravam na Universidade. Servia para lembrar ao professor que ali estavam sujeitos pertencentes ao MST e futuros professores de sem-terrinha, o que os distinguia dos valores/saberes da educação burguesa.

Esse duplo movimento - para si próprios e para o professor - produzia uma tomada de superidentificação que tornava visível o invisível: as FD em delimitação recíproca envolvidas naquela experiência. Assim a prática ritualística da mística construía uma fronteira invisível, mas perfeitamente tangível entre as FD que afetavam estes dois grupos reunidos no espaço da sala de aula, transformada momentaneamente em um entre-lugar - nem mais Universidade, nem mais um acampamento do MST - e

\footnotetext{
${ }^{20}$ Pêcheux entende resistência como "não entender ou entender errado; não "escutar" as ordens; não repetir as litanias ou repeti-las de modo errôneo, falar quando se exige silêncio; falar sua língua como uma língua estrangeira que se domina mal; mudar, desviar, alterar o sentido das palavras e das frases; tomar os enunciados ao pé da letra; deslocar as regras na sintaxe e desestruturar o léxico jogando com as palavras....". (Pêcheux, 1982/1990, p. 17) (Os destaques são meus).
} 
este entre-lugar se constituía na clara evidência de que a pulsão político-social que movia os sujeitos situados nos dois lados daquela fronteira ideológica não era idêntica, ainda que ligados por laços de aliança e colaboração. Como pode-se perceber, educação e mística aparecem fortemente entrelaçadas, indicando que tais práticas se revestem de um forte movimento de resistência à educação burguesa.

Quando esse grupo concluiu seu curso, foi chegada a hora da formatura. E, como não poderia deixar de ser, a mística foi parte constitutiva daquela prática de colação de grau. Para marcar aquele acontecimento, no dia da formatura, o MST trouxe seus símbolos e cânticos. Mas isso ainda não era suficiente. Necessitavam da terra no palco do Salão da UNIJUÍ. E terra foi colocada naquele chão, representando para eles mesmos e para a Universidade o seu lugar social, o seu lugar de pertença. Uma mística preparada especialmente para aquela solenidade, pois a formação específica de professores para a escola do MST era algo da ordem da raridade, era um acontecimento histórico, representava a concretização de uma utopia e, como tal, tinha de ser diferente. E nada mais simbólico para sinalizar a especificidade daquela colação de grau do que trazer a terra para a Universidade, para junto deles, a terra para nela pisar e assim rememorar para eles mesmos que tipo de professores estava saindo dali, mas não apenas isso. Também visava lembrar à própria Universidade o perfil daquela turma de formandos e assim marcar aquele acontecimento histórico.

Mais uma vez a fronteira invisível, o entre-lugar, tornou-se momentaneamente tangível pelo viés da mística. Diria que essa terra no palco rememorou a aliança que havia sido firmada entre a UNIJUÍ e o MST: de um lado, sem-terra buscando na Universidade a concretização de um objeto de desejo - preparar-se para também ocupar a escola e formar os sem-terrinha, de acordo com os saberes por eles entendidos como substantivos. De outro, a Universidade, abrindo suas portas para o diferente, para um Movimento que luta, no mínimo, pela transformação das condições de vida do homem no campo. Uma aliança entre FD diferentes, baseada na possibilidade de tentar dar concretude a um sonho, que uniu esforços para transformar uma utopia em realidade ${ }^{21}$.

\footnotetext{
${ }^{21}$ E durante algum tempo, efetivamente, este sonho tornou-se realidade pela conquista de outra utopia: as escolas itinerantes do MST eram possíveis porque seus professores eram membros do MST. Sonho este que foi derrubado posteriormente por um ato do Governo. Mas esta já é uma outra história...
} 


\section{Suspendendo a reflexão}

As místicas aqui analisadas são um recorte entre tantas outras e diferentes místicas. Mas não importa a diversidade, o que interessa é captar como um ritual pode funcionar politicamente como um gesto de resistência e simultaneamente na captura e recaptura do sujeito, em seu processo de identificação e reidentificação. Pêcheux afirma que o sujeito ideológico

É interpelado - constituído sob a evidência da constatação que veicula e mascara a "norma" identificadora: "um soldado francês não recua" significa, portanto, "se você é um verdadeiro soldado francês, o que, de fato, você é, então você não pode/deve recuar". Desse modo, é a ideologia que, através do "hábito" e do uso, está designando, ao mesmo tempo o que é e o que deve ser [...] É a ideologia que fornece as evidências pelas quais "todo mundo sabe" o que é um soldado, um operário, um patrão, uma fábrica, uma greve, etc. [...] (PÊCHEUX, 1975/1988, p. 159-160).

Glosando Pêcheux, é possível dizer que é a ideologia que faz com que um semterra saiba o que é um sem-terra, bem como é a ideologia que faz com que um sem-terra saiba distinguir a educação desejável da educação inadequada para os sem-terrinha, para retomar aqui a palavra de Bauman, citada mais acima. Este é o funcionamento da mística enquanto pulsão de natureza político-social ${ }^{22}$. É ela um dos motores que garantem a construção de uma identidade Sem Terra bem como a produção coletiva do desejo do sujeito sem-terra.

A mística é, em suma, um ritual político que, a um só tempo, oferece resistência às práticas do outro e reafirma a própria identificação, resultando daí uma superidentificação. Por seu viés, jovens e recém-chegados à luta são interpelados. É dessa prática político-ritualística que os sem-terra tiram sua força e reafirmam suas convicções e seu pertencimento ao movimento. Uma prática através da qual afirmam e reafirmam sua identificação aos saberes do Movimento, reforçando sua luta e atualizando a memória social do Movimento. E, assim, vão tecendo sua trilha em direção à utopia que "está lá, distante, no horizonte, impulsionando-os para que não cessem de caminhar". ${ }^{23}$

\footnotetext{
${ }^{22}$ Com isto não estou afirmando que todos os acampados se mantêm fiéis aos saberes do MST. Há aqueles que mantêm fortemente esta identificação, mas, como nos disse Pêcheux (1978/1988, p. 301), "não há ritual sem falhas, enfraquecimento e brechas". Por conseguinte, há acampados que se contraidentificam (Pêcheux, 1975/1988, p.215) com os referidos saberes, a eles resistindo e, desta forma, se rebelando contra o Sujeito. Essa rebeldia nasce, talvez, do fato de que, ao receberem seu lote de terra, ultrapassam imaginariamente uma outra fronteira invisível (Pêcheux, 1982/1990, p.14-15) que os coloca imaginariamente do outro lado e, de sem-terra, se transformam em proprietários rurais... Mas esta também já é outra história.

${ }^{23}$ Citação livremente adaptada de Fernando Birri, via Eduardo Galeano.
} 


\section{Referências bibliográficas}

BAUMAN, Zygmunt (2000). Em busca da política. Rio de Janeiro: Zahar.

BOGO, Ademar (2009). O MST e a cultura. 3. ed. São Paulo: Movimento dos Trabalhadores Rurais sem Terra.

CALDART, Roseli S. (2000). Pedagogia do Movimento Sem Terra: escola é mais do que escola. Petrópolis: Vozes.

CAMINI, Isabella (1998). O cotidiano pedagógico de professores e professoras em uma escola de assentamento do MST: limites e desafios. Porto Alegre: PPGFACED/UFRGS. Dissertação de mestrado.

FERNANDES, Marco. ( 2011). Luta que cura! http://passapalavra.info/2011/05/40366 . Acesso em 29/07/2014.

FOUCAULT, Michel (1970/1996). A ordem do discurso. são paulo: Ed. loyola.

FREUD, Sigmund (1915/1974). O instinto e suas vicissitudes. Ed. Standart Brasileira das obras Psicológicas completas de Sigmund Freud. Vol. XIV. São Paulo: Imago.

GUATTARI, Felix \& ROLNIK, Suely (1986). Micropolítica: cartografias do desejo. Petrópolis: Vozes.

HERMANN, Jacqueline (2010). Haja previsões. Revista de História. com.br http://www.revistadehistoria.com.br/secao/capa/haja-previsoes . Acesso em 30/07/2014.

INDURSKY, Freda (1999). De ocupação a invasão: efeitos de sentido no discurso do/sobre o MST. In: INDURSKY, Freda \& LEANDRO FERREIRA, Maria Cristina (Orgs.). Os múltiplos territórios da Análise do Discurso. Porto Alegre: Sagra-Luzzatto.

(2000). A função do porta-voz no discurso sobre o MST. Alea: Estudos Neolatinos, PPG Letras Neolatinas, UFRJ, v.2, n.2, set.

(2005) O político e o jurídico na constituição das subjetividades sociais. Gragoatá, Niterói, n.18, p.97-110, 1. sem.

(2006).Identificação e contra-identificação: diferentes modalidades de subjetivação no discurso do/sobre o MST. In: MARIANI, Bethania (Org.). A escrita e os escritos: reflexões em análise do discurso e psicanálise. São Carlos, SP: Clara Luz.

(2013). A emergência do sujeito desejante no discurso do MST. Gragoatá, Niterói, n.34, p.27-38, 1. sem.

PÊCHEUX, Michel (1975/1988). Semântica e discurso. Campinas: Ed. da UNICAMP.

(1978/1988). Só há causa daquilo que falha ou o inverno político francês: início de uma retificação. In: PÊCHEUX, Michel. Semântica e discurso. Campinas: Ed. da UNICAMP.

(1982/1990). Delimitações, inversões, deslocamentos. Cadernos de Estudos linguísticos, Campinas, n. 19, p. 7-24, jul./dez.

RANULFO, Pedro. A força que anima os militantes. Cadernos de Formação, n.27, p.8, MST. 
Para citar essa obra:

INDURKY, F. O ritual da mística no processo de identificação e resistência In: RUA [online]. 2014, Edição Especial - ISSN 1413-2109. Consultada no Portal Labeurb Revista do Laboratório de Estudos Urbanos do Núcleo de Desenvolvimento da Criatividade.

http://www.labeurb.unicamp.br/rua/

Capa: Escola itinerante no acampamento do MST Valmir Motta de Oliveira Disponível em: http://www.jornalfolhadoiguacu.com.br/?p=8557

\section{Laboratório de Estudos Urbanos - LABEURB}

Núcleo de Desenvolvimento da Criatividade - NUDECRI

Universidade Estadual de Campinas - UNICAMP

http://www.labeurb.unicamp.br/

\section{Endereço:}

LABEURB - LABORATÓRIO DE ESTUDOS URBANOS

UNICAMP/COCEN / NUDECRI

CAIXA POSTAL 6166

Campinas/SP - Brasil

CEP 13083-892

Fone/ Fax: (19) 3521-7900

Contato: http://www.labeurb.unicamp.br/contato 